\title{
Your sister in Babylon sends her love: Towards prophetic solidarity in post-apartheid South Africa
}

\begin{abstract}
Author:
Maarman S. Tshehla ${ }^{1}$

Affiliation:

${ }^{1}$ Research Institute for

Theology and Religion, University of South Africa,

South Africa

\section{Note:}

This article forms part of the special collection on 'Doing urban public theology in South Africa: Visions, approaches, themes and practices towards a new agenda' in HTS Teologiese Studies/Theological Studies Volume 70, Issue 3, 2014. The collection is the result of the project 'Urban Public Theology', which was initiated by the Institute for Urban Ministry but later expanded to include several academic departments and institutes at the University of Pretoria (UP) and University of South Africa (UNISA). The leading centres in this regard were the Centre for Contextual Ministry (UP) and the Research Institute for Theology and Religion (UNISA).
\end{abstract}

\section{Correspondence to:}

Maarman Tshehla

\section{Email:}

tshehms@unisa.ac.za

Postal address:

PO BOX 392, University of South Africa, Pretoria 0003, South Africa

\section{Dates:}

Received: 17 July 2014

Accepted: 21 July 2014

Published: 20 Nov. 2014

\section{Read online:}

How does a self-respecting Christian from Galilee who now finds himself based near the seat of empire relate to power in light of his faith? How are his admonishments, especially those which relate to the public arena, to be appropriated by those living on the periphery of the empire? I reflect on these questions from the vantage point of a South Africa in which on the one hand erstwhile prophets are being haunted by the vagaries of power and on the other the Church is apparently as powerless as never before.

\section{Introduction}

Milestones have the blessed value of coaxing us into reflection about the paths our lives are on. Recent 20-year celebrations alongside the fifth general elections of post-apartheid South Africa are cause for such reflection. In particular, those Christians who have been conscious through the volatile 1980s, the miraculous 1990s, as well as the first two decades of democratic South Africa do bear the burden of pondering whether and to what extent things may have changed. At first glance, it appears as if the Church's prophetic role was so tied up with apartheid that when the latter fell away, the former expired along with it. This is, however, most disconcerting because the socio-economic asymmetries associated with apartheid persist ever more sharply in modern South Africa. The need for a voice echoing in the wilderness on behalf of the downtrodden has never been greater. This article therefore seeks to weave a narrative around questions pertaining to the place of prophetism within present-day South Africa. It draws primary guidance from part of the interaction between John and Jesus as reported by the Synoptists, and secondary inspiration from the words and socio-literary context of 1 Peter 5:13.

\section{Reading contexts}

Social analysis is a prized starting point within liberation hermeneutics. Both the ancient and modern socio-political contexts guide interpretation as the Bible gets deployed as a resource in the struggle both against detected ills and for noble ideals. Present realities resonate with and inspire engagement with realities projected through biblical texts. And so, essentially, biblical 'texts are read against the background of neo-colonialism and economic oppression in Africa' (Ukpong 2006:63). The overt emphasis on economics and politics does lead some to question the theological value of such an undertaking. But liberationists prefer not to declare peace where there is none in order simply to whitewash flimsily built walls (Ezk 13:10) in a misguided pursuit of objective (that is 'sterile' and therefore socially impotent) interpretations of the Bible.

Notwithstanding the contextual approach's shortcomings, reality is that within any concrete context, 'the very act of reading or interpretation (exegesis) is always a political act.' There is no denying 'the work the New Testament is doing in church and society' and, by extension, whether 'actively or merely by being silent', the contribution of New Testament scholars in relation to, or in service of, 'structures of oppression and exploitation' (Craffert 2007:180). Put differently, those of us who handle the Bible need to be attuned to what is going on within church and society vis$\grave{a}$-vis how readings of the Bible and exploitative social structures may be mutually reinforcing one another. We are sensitive to these realities in our day because we recognise their place in the contexts out of which the biblical texts emerged (Craffert 2007:183).

Coming then to our context, South Africa's democracy faced its first real test in the 07 May 2014 general election. Since the euphoria of the 1990s, our rainbow nation's ordinariness - even 'nakedness' - is now evident to all. The jury is still out on how well the test was negotiated, particularly in light of election-rigging allegations: first in the Tlokwe district's by-elections earlier in 2014 (Groenewald \& Sithole 2014) and afterwards in Gauteng during the national election (Mkhize 2014). All these developments have been compounded by the dark cloud hanging over the Electoral Commission's head (SAPA 2014).

How to cite this article: Tshehla, M.S., 2014, 'Your sister in Babylon sends her love: Towards prophetic solidarity in post-apartheid South Africa', HTS Teologiese Studies/Theological Studies 70(3), Art. \#2789, 6 pages. http://dx.doi.org/10.4102/hts.v70i3.2789

Copyright: @ 2014. The Authors. Licensee: AOSIS OpenJournals. This work is licensed under the Creative Commons Attribution License. 
Having astonishingly learnt so little from the experiences of fellow African countries which gained political independence ahead of South Africa, it is becoming clear that the 1990s transition was managed so carefully as to ensure that even 20 years on, very little has changed in real terms vis-à-vis the average South African's quality of life (Booysen 2014). What changes there have been simply pale in the light of what has remained intact:

The political sphere changed dramatically ... By comparison, social and economic relations and structures ... displayed quite striking levels of continuity. Those who owned factories or firms before the elections in April 1994 continued to own them when the ANC-led government took office. Wealth - assets in property or shares or savings accounts - stayed in the same hands. The mining conglomerates, banks and finance houses which dominated the apartheid economy remained intact and dominated the post-apartheid economy. (Bundy 2014:45-46)

Unemployment festers even as social welfare spending is increased in efforts to pacify that half of the population which both lives below the poverty line and continues to witness on daily basis the growing gap between the haves and the havenots. A recent article in the Financial Mail by Claire Bisseker (2013) entitled 'SA's welfare net keeps social stability' cogently ponders the sustainability of this trend. Instead of abating, the economic 'legacy of the past unjust rule' (Kistner 1994:2) has sustained itself in the new dispensation and even gone so far as to convert erstwhile prophets into its retainers. In Richard Cummings' (1996:277) wry turn of phrase: 'Politicians may come and go, but as the De Beers ad says on television, "a diamond is forever"'. Recognising this eventuality, shrewd politicians accordingly align themselves with diamonds.

The story of the country's current deputy president, Cyril Ramaphosa, provides a telling example of the sorts of challenges facing post-apartheid South Africa. He started out as a formidable leader of the National Union of Mineworkers (NUM), a role which gave De Beers and friends not a few long sleepless nights. Then, following the 1994 'miracle', he became the distinguished co-author of our celebrated Constitution. When in 1997 it seemed as though his political career had ebbed, he found refuge in the everlasting diamonds. Chronos and Ananke are yet to pen their take on his current role in government, although his contentious association with both the 'Marikana massacre' and the 'Boer' epithet may yet prove to have been portentous signs (Hlongwane 2012). But with Ramaphosa one is fascinated by the captivating facets of marriage between political power and mineral wealth: the sort of marriage which is by no means exclusive to the South African political arena. This marriage, some contend, blinds politicians to the reality that:

'What is good for Anglo-American is not necessarily good for South Africa.' This is not to indicate that Anglo-American is governed by evil people, but to indicate that any company as close to a virtual monopoly as Anglo-American (with De Beers) is also very close to the non-acceptable extremes of an economic dispensation. (Hovland 1992:73)

The controversial persistence of categories such as 'Boer' and phrases like 'police brutality' within democratic South Africa is another clear indication of how little things have changed as well as how resilient the ways of the past are proving to be. Yet, however many anti-apartheid prophets may have fallen along the way, South Africa possesses the rich legacy of struggle for justice. Is the legacy of the struggle for justice as well-preserved within the value systems of South Africans as the legacy of unjust rule clearly seems to be? Is the Church in South Africa awake to the need to safeguard ...

its independence from the state not for its own sake, but for the sake of justice in order to carry out its 'basic societal responsibility' as 'the conscience of society'? (Hovland 1992:68-69; [emphasis original])

\section{Prophets do come and go}

Current indications are that the prophets have abdicated, or, in more politically palatable terms, their era has come and gone. In fact, they have self-admittedly been thrown into some rather embarrassing disarray. One senior theologian reflects as follows on why liberation theology in general or black theology in particular, is no longer a force to be reckoned with in present-day South Africa: and all this despite some burning issues on the ground:

There have been no major seminars or conferences on black theology in South Africa since 1996. Nor have there been any significant or groundbreaking publications since then. This is regrettable in view of the changes that have taken place in the country since the fall of apartheid and the 1994 democratic elections. It is regrettable also in light of the new social issues that require urgent theological, especially theological-ethical, reflection and response. (Motlhabi 2005:54)

But why and how did this situation arise? In a nutshell, it is because many 'veteran black theologians have left academic work and gone into administrative positions.' Furthermore:

$[T]$ he few who remain in the academy seem, like the whole theological climate now existing in the country, to have been thrown into confusion about what their next step or plan of action should be, and to be paralysed by the new circumstances with their new sets of problems. (Motlhabi 2005:54)

Yet the new circumstances are desperately crying out for sustained theological-ethical critiques!

Could it perhaps be that the quality of black theology students has all of a sudden dropped? The problem seems more likely to be that the younger black theologians are most eager to follow the veteran prophets' example of responding positively to the melodious call of the diamond along with its promise of eternal bliss. They do not mind coming and going, so long as the exit handshakes are adequately studded. The result is that the voiceless have to fend for themselves and those who are in power have no thorns giving them sleepless nights. Perhaps the prophets of the anti-apartheid movements should simply return as prophets of the postapartheid class struggle: after all the 'class-struggle' had always been a major component of their socio-political analysis and theological response (Mosala 1989, 1994). In many ways, John the Baptiser's ministry resembles that of pre-1994 South African prophets. The difference arises when John accepts a fate which South Africa's erstwhile prophets appear unwilling to even contemplate. 


\section{Faith does come and go}

It may very well be an inescapable part of human nature to expect benefits to accrue on account of services selflessly performed as heralds of a new dispensation. 'Perhaps Jesus of Nazareth is not the Messiah who was to come; perhaps we should yet await the real thing', pondered John from inside a prison cell. Having given up the more politico-economically rewarding priestly occupation for the unpopular prophetic vocation, is it fair that John should in the end merely rot in jail without so much as a visit from his towering comrade? ${ }^{1}$ But he had been incarcerated for speaking truth to adulterous power: and from within jail he refused to change his tune despite Herod's fascination with him. In the end, he was killed because 'like the prophets of old' (Mk 6:15) John was not prepared to declare peace where there is none in order simply to whitewash flimsily built walls. It is fitting indeed that Jesus should acknowledge John as a giant of a prophet: 'Yes, I tell you, and more than a prophet' (Mt 11:11).

John's crisis as reported by Matthew (11:1-19) is not about whether to adapt his message in order to secure himself a more pleasant existence. That seems not to have been an option for true prophets. The crisis concerned unrealised divine intervention. Why will God not vindicate true prophets: why should Herod appear to have the last laugh! Why does Jesus - if he truly is the long-awaited Messiah - seem to be unbothered by the pitiful state of his herald? What is a prophet to do at a time like this? It is not unreasonable that he should ask if things are indeed as he believed them to be or perhaps he was misguided. But, it must be stressed, it does not occur to the true prophet to alter the message in order to secure a cosier life. In fact, in a telling contrast to John's unflinching resolve, it was Jesus who, when facing a similar anguish of an 'undeserved and unjust suffering' (Michaels 1989:60), did for a second consider 'not going through with it' (cf. Mt 26:39). Thankfully, he must have quickly recalled the advice he had earlier given his disciples: 'So you also, when you have done everything you were told to do, should say, "We are unworthy servants; we have only done our duty"' (Lk 17:10). Still, for that fleeting moment, Jesus experienced that loneliness which had earlier made John swallow his pride and seek Jesus' emotional support:

Let me tell you this: faith comes and goes. It rises and falls like the tides of an invisible ocean. If it is presumptious to think that faith will stay with you forever, it is just as presumptious to think that unbelief will. (Flannery O'Connor in De Gruchy 1986:9)

Costly as the liberation struggle was, to date the tangible fruits of democracy elude many South Africans, rendering this not at all a time to declare peace and prosperity in the land. The buffer zone provided by the so-called 'black middle class' is in my view fairly tenuous. Aside from the heavily taxed professional workforce, the rest of the 'black

1.The parallel story of South African convicts who are still among us years after they were released from prison on the basis of 'terminal illnesses' suggests itself as a fascinating contrast. But I will not indulge them here lest I make light of a genuine hero like the Son of Zechariah who stayed true to the prophetic cause until he met hero like the Son of Zechariah who stayed true to
up with the very telling anticlimax of martyrdom. middle class' is populated by persons who possess access to political power which is increasingly proving to be just the most effective currency for the acquisition - and/or disposal - of economic advantage.

There is something of an irony here. During the four decades prior to our democracy, South Africans died fighting against dompasses and for the ideals espoused inter alia by the Freedom Charter. In the two decades since the dawn of democracy large numbers of 'previously disadvantaged' South Africans are dying because they lack dompasses (that is to say, struggle credentials and/ or political connections) that would allow them entry into post-apartheid South Africa's exclusivist economic bantustans. ${ }^{2}$ They die not only from neglect at the hands of their erstwhile comrades. They die also from acts of brutality and repression, sanctioned or demanded by their comrades who must swiftly set good examples against real or imagined dissent. In other words, as under apartheid, South Africans continue to die for demanding the realisation of such ideals as the living wage and land redistribution. Can justice be any more deferred? Will faith in the cause survive such an onslaught?

To reiterate, political power may come and go, but economic power is forever, and special access thereto should be protected at all cost. I am neither an alarmist nor a prophet of doom, but if the 2014 election results were anything to go by, the people of South Africa appear to be losing faith in the once-untouchable African National Congress. Disillusionment breeds unbelief, which can take faith's place far more easily than faith can replace unbelief. It is not that faith cannot take the place of unbelief: such a development is just far more taxing than its obverse. But faith in ktisis (a human 'creation' or 'institution') is not to be confused with faith in the living God who still hears the cries of the oppressed and responds accordingly.

\section{Kairoi do come and go}

Today, as during apartheid days, 'God is called upon by some to bless those in authority; God is also evoked by others to remove those in power from office' (De Gruchy 1986:4). Contrary to appearances people on the ground know full well that God is to be wrested away from the clutches of evil persons. The children of the prophets will engage in social analysis and endeavour to seize the moment of crisis which is staring them in the face. Failing to see how this could be it, they will labour towards the promise for which so many have already laid down their lives. There is a relevant precedent in this regard:

Some of the pastors, theologians and church workers who were appalled by the iron fist of the police, came together to write the Kairos Document. They said that it was a moment of truth for the Church and that it was no longer possible to remain silent

2. The comparative aspect may be difficult for me to prove (blacks were excluded from is quite sensible: 'Political and economic is quite sensible: 'Political and economic power are probably more closely aligned, twenty years into ANC rule, than they ever were under the National Party' (Bundy 2014:152). 
or to indulge in vague generalities. The Kairos Document was published on 25 September 1985. Today, exactly five years later, with violence of horrific proportions and the real possibility of even more violence to come if the perpetrators are not exposed soon, we face a crisis, a moment of truth, that is even more of a kairos [than] 1985. (Institute for Contextual Theology [ICT] 1990:1)

The Church is definitely not as organised today as it was during apartheid, but the masses' experience of disproportionately meted out violence remains just as horrific. Daily news bulletins are replete with déjà vu nightmares that leave one wondering when and why the notorious state of emergency was reinstated. The prophetic ICT document just quoted emerged in 1990 as part of social analysis carried out in the heat of some well-orchestrated 'black-on-black violence'. I am compelled to cite it at some length because it too confirms, among other things, how much things have stayed the same. Also, I quote it at length in order that those who wish to follow in the great tradition of South Africa's prophetic theology will thus have a decent example of theologically informed social analysis to emulate. As a matter of fact, it splendidly echoes the realities of some among us in 2014, and so models the sort of message the Church should be proclaiming to power in 2014:

We cannot be fooled by the propaganda, the cover-ups, the smokescreens, the lies and the confusion ... We cannot afford to rely upon superficial explanations ... there is more to it than meets the eye ... At first there was hope but for those whose sufferings have continued and even become worse despite all the talk about a new South Africa, hope has turned into disillusionment. (ICT 1990:2-3)

One should in due course write at length about the disillusioning insult that some of the 'superficial explanations' amount to. Insults, of course, are the favourite pastime of those who are drunk with power. If this 1990 analysis is apropos to the post-apartheid public theological project, then its lucid concluding observations are most urgent, especially against the backdrop of recent events in South Africa:

A strong, clear prophetic word is needed. The sins of the wicked must be exposed and condemned. We dare not sit back and wait because the evidence is not yet technically complete, while hundreds of people are being slaughtered on our streets. We must speak up, we must raise questions, we must take risks, we must call for inquiries ... We must not be afraid to point a finger in the direction of those who are conspiring against us all ... Apartheid, racism, oppression and violence are still very much part of the system that rules our lives - despite all the promises of a different future ... The primary task of the Church at this moment, then, is not to call for peace but to call for justice. (ICT 1990:13-14; [emphasis original])

\section{Babylons do come and go}

Not only do the victims of history regularly lack the capacity to represent themselves, but the victors generally find bizarre fulfilment in belittling the legacy of those prophets that they were able to crush. But however long one's hold on power may seem, it too has an expiry date. In fact we do not celebrate the emperor's achievements, his Res Gestae, on the basis of the incidence of some precarious and unevenly distributed 'peace'. Regardless of whether he was in power for 4 or 30 years, we remember the emperor in relation to how justly he treated all his subjects, and for that matter not only those who lived in Rome. After all, Pax Romana does not necessarily imply that abuse, persecution and deferment of justice were absent in the various regions of the empire. On the contrary, it means essentially that the emperor was given no reason to visit his wrath upon those regions. Consequently, where retainers celebrated Pax Romana, others who were on its receiving end experienced Babylon.

In indirectly referring to his location as Babylon, the author of 1 Peter was drawing on a metaphor with which contemporary Christians were familiar (Achtemeier 1996:353). Indeed the letter is addressed to 'foreigners and exiles' (1 Pt 2:11). Even though 1 Peter's writer does not betray his feelings concerning this Babylon, the metaphoric designation in itself is intended to assure the letter's recipients of God's impending judgement upon this land of their exile. Their experiences as exiles under Pax Romana outranked their specific localities. Hence, even though 1 Peter claims to have been meant for Christians scattered in several regions of Asia Minor, a good number of scholars feel that 'any specific historical designation' is secondary (Tite 1997:43).

Furthermore, there are good indications that 'she who is in Babylon' (1 Pt 5:13) along with the writer of the letter were all 'in the same boat' as the letter's recipients, a boat seeking to negotiate the storms associated with being 'a counterculture in Roman society' (Michaels 1989:38). This 'common ground between the Church in Babylon and the addressees' (Martin 1992:76) accounts for 1 Peter's nickname as a letter from the homeless to the homeless (cf. Elliott 1982; Thurén 1990:160). In other words, the Church in Rome from where 1 Peter is being written is as much in Babylon as the churches elsewhere in the empire. Babylon or Rome is at once the heart of the empire and the metonym of the glorious empire.

The letter's recipients were guilty of the 'politically dangerous' and subversive crime of 'transgressing social boundaries' (Horrell 2008:84) by recognising not the emperor but Christ as their final authority. Refusal to worship the emperor carried dire consequences, including the death penalty. It follows that some time must be expended in addressing this critical matter among Christians. Therefore 'the letter confronts this experience and encourages and instructs its readers' (Horrell 2008:77) to negotiate this situation without losing neither faith nor face. The heart of the instruction is found in 1 Peter 2:17: 'Honour everyone. Love the family of believers. Fear God. Honour the emperor.' It is not hard to see that the emperor is something of a 'last but not least' entry and also that he is to be regarded and treated no differently from 'everyone' - that is every other human ktisis (1 Pt 2:13). 'Although this instruction does, rather crucially, express a degree of resistance to imperial demands ... it clearly urges the Christian recipients of the letter to live in a way which positively respects Rome's rule, honouring the emperor, just as they honour all people (and not just believers, who are specifically to be loved)' (Horrell 2008:82; emphasis added). 
Put negatively, extend to the emperor no special regard beyond that which is due to every other human being or office: 'The emperor, in other words, is only one instance and by no means a unique one - where this pattern of conduct is appropriate' (Horrell 2008:87). To bring the matter closer home, the same degree of respect that is due to the president is equally due to the miner in Rustenburg, a member of the opposition in parliament, the office and person of the public protector, and so forth. None of these human beings and/ or human institutions are to be feared: to be feared is God's exclusive right! If suffering must result from this Christian attitude towards the emperor, know that it is an honour to suffer as a Christian (but not as a murderer, thief, etc.)! Babylons will come and go, as will politicians, but truth, justice and faith in the living God ought not to be subject to the whims of prevailing situations.

\section{Conclusion \\ Out of Babylon with love}

The greetings that she who is in Babylon sends along with the epistle are more than mere traditional salutations: they 'expressed the unity of the one church scattered throughout the world ... and its solidarity in suffering and mission' (Boring 1999:180-181). She who is in Babylon sends with this letter her pledge of solidarity as a fellow-exile for the sake of Christ (Marshall 1991:175). She too will not bow a knee to the emperor because she is already pledged to Christ. Even while residing in the vicinity of the seat of empire, she too risks death daily by unapologetically placing the emperor at the same level as all other human institutions. Like John the Baptiser, and many other prophets of truth and justice over the centuries, she risks martyrdom by continuing to be overtly critical of any and all abuse of power as well as by refusing to be overawed by the splendour of Babylon.

The Petrine community - which gave us the complex ${ }^{3}$ treatise whose surface we have hardly scratched herein - must be embarrassed at how little weight the 'Christian' tag has come to carry in post-apartheid South Africa. 'After all, the socio-religious context in which Peter preached and in which Paul wrote his letters was not entirely unlike that in which the Christian Church of the early twenty-first century finds itself', namely, a context characterised by 'numerous competing ideologies, religions and philosophies, in a market-place of ideas and spiritualities' among citizens 'who very often have little or no formation in the Christian faith' (Billings 2012:480). These were the very contextual realities which helped sharpen the believers' faith (cf. 1 Pt 1:7). But their resolve in the face of danger is something that the postapartheid South African Church desperately needs. 'Where is that "genuineness of faith" which results from being "tested by fire"'?, 1 Peter's earliest audiences inquire. 'Why do they bear the name "Christian" if they would go so far as to sell their own family members in exchange for the transitory comforts of Babylon?'

3. While 1 Peter 'is one of the most difficult books to translate in the whole New Testament' (Arichea \& Nida 1980:2), New Testament interpreters cannot shy away from endeavouring 'to shed some light on the complex social dynamics implied by this text and ultimately to advance the understanding of early Christianity's engagement with its environment' (Elliott 1986:62).
In this article, without sufficient explication of all pertinent factors, I have tried to demonstrate how appreciating the complexity of ancient social realities, promotes better appreciation of the complexity of contemporary social dynamics as well as offers ways whereby present-day Christians can concretely engage with the challenges of their day. Much as 1986 saw John de Gruchy give his inaugural lecture under the shadow of Devil's Peak, ${ }^{4}$ the author of 1 Peter ventured his thoughts from under the shadow of Babylon and therefore in direct engagement with the acute issues of empire. This precarious context made him offer some bold and sophisticated Christian counsel whose value persists even for 21st century Christians. After all we too, like the early Christians, live by faith in hope and anticipation of 'God's reversal of [the unpleasant exilic] situation' (Martin 1992:273-275).

I have engaged in some wild criss-crossing between the ancient and modern worlds, and employed many concepts without affording them due definition. That being as it may, I am afraid not much can be said to the victims of legalised abuse of power, to the poor and marginalised citizens of postapartheid South Africa, to those for whom justice is 'blind' only in the slang-sense of the word, meaning unattainably kwaai. Perhaps a pledge of solidarity is all that remains: She who dwells under the shadow of the Union Buildings - and thus has better access to resources than you do - sends you her love and camaraderie. Cognisant of being under constant monitoring, she nevertheless draws strength from her hope in God, for, ' $[i] \mathrm{f}$ the righteous are scarcely saved, what will become of the godless and unjust?' (1 Pt 4:18).

\section{Acknowledgements Competing interests}

The author declares that there are no financial or personal relationships that may have inappropriately influenced him in writing this article.

\section{References}

Achtemeier, P.J., 1996, 1 Peter, Fortress, Minneapolis, MN.

Arichea, D.C. \& Nida, E.A., 1980, A translator's handbook on the First Letter from Peter, UBS, New York, NY

Billings, B.S., 2012, "'As some of your own prophets have said": Secular and non-canonical literature in the New Testament and some (post) modern parallels,' The Expository Times 123(10), 479-485. http://dx.doi. org/10.1177/0014524612444542

Bisseker, C., 2013, 'SA's welfare net keeps social stability', in Financial Mail, viewed 08 June 2014, from http://www.financialmail.co.za/fm/Features/2013/07/18/sas-welfare-net-keeps-social-stability

Booysen, S., 2014, 'Twenty years of South African democracy: Citizen views of human rights, governance and the political system', in Freedom House, viewed 14 June rights, governance and the political system
2014, from http://www.freedomhouse.org

Boring, M.E., 1999, 1 Peter, Abingdon, Nashville, TN.

Bundy, C., 2014, Short-changed? South Africa since apartheid, Jacana, Auckland Park.

Craffert, P.F., 2007, 'New Testament Studies - Preventing or promoting a humane society?', Religion \& Theology 14(3/4), 161-205. http://dx.doi.org/10.1163/102 308012X13397496507144

Cummings, R, 1996, 'A diamond is forever: The triumph of Mandela, the survival of Chief Mangosuthu Buthelezi and F.W. de Klerk, and how the African National Congress ended up on the United States payroll', in M. Agonafer (ed.), Africa in the contemporary international disorder: Crises and possibilities, pp. 263-286, University Press of America, Lanham, MD.

4.'Three symbols of the South African context lie in the shadow of Devil's Peak: the Houses of Parliament, symbol of white power; District Six, symbol of the oppression of apartheid; and the University of Cape Town, symbol of a liberal education. Doing of apartheid; and the University of Cape Town, symbol of a liberal education. Doing
theology under Devil's Peak is God-talk in relation to each of these realities' (De Gruchy 1986:2). 
De Gruchy, J.W., 1986, 'Doing Christian theology in the context of South Africa, or God-Talk under Devil's Peak', inaugural lecture, University of Cape Town, Cape Town, 17 September.

Elliott, J.H., 1982, A home for the homeless: A sociological exegesis of 1 Peter: Its situation and strategy, SCM Press, London.

Elliott, J.H., 1986, '1 Peter, its situation and strategy: A discussion with David Balch', in C.H. Talbert (ed.), Perspectives on First Peter, pp. 61-78, Mercer University Press, Macon, GA

Groenewald, Y. \& Sithole, S., 2014, 'Tlokwe vote "fixed"', City Press, viewed 18 May 2014, from http://www.citypress.co.za/politics/tlokwe-vote-fixed-2/

Hlongwane, S., 2012, 'Cyril Ramaphosa's Marikana email batters ANC heavyweight's reputation', Daily Maverick, viewed 08 July 2014, from http://www.theguardian. $\mathrm{com} /$ world/2012/oct/24/cyril-ramaphosa-lonmin-email-reputation

Horrell, D.G., 2008, 1 Peter, T\&T Clark, New York, NY.

Hovland, T.H., 1992, 'The role of the church in a pluralist society', Journal of Theology for South Africa 80, 65-75.

Institute for Contextual Theology (ICT), 1990, Violence, the new Kairos: Challenge to the churches, ICT, Braamfontein.

Kistner, W., 1994, The legacy of the past in the New South Africa: Tentative theological reflections on the amnesty issue in the context of a national policy of reconciliation, Ecumenical Foundation of Southern Africa (EFSA) Institute for Theological and Interdisciplinary Research, Bellville.
Marshall, I.H., 1991, 1 Peter, Intervarsity Press, Downers Grove, IL.

Martin, T.W., 1992, Metaphor and Composition in 1 Peter, Scholars Press, Atlanta, GA.

Michaels, J.R., 1989, 1 Peter, Word Biblical Themes, Word Publishing, Dallas, TX.

Mkhize, V., 2014, 'Residents: Alexandra is like a war zone', Eye Witness News, viewed 08 July 2014, from http://ewn.co.za/2014/05/10/Alexandra-A-war-zone

Mosala, I., 1989, Biblical hermeneutics and black theology in South Africa, Eerdmans, Grand Rapids, MI.

Mosala, I., 1994, 'Why apartheid was right about the unliberated Bible: Race, class and gender as hermeneutical factors in the appropriation of Scripture', Voices $17(1), 151-159$.

Motlhabi, M.G.B., 2005, 'Black theology in South Africa: An autobiographical reflection', Studia Historiae Ecclesiastica 31(2), 37-62.

SAPA, 2014, 'Tlakula files Concourt application against dismissal', Mail \& Guardian, viewed 10 July 2014, from http://mg.co.za/article/2014-07-10-tlakula-appeals-toconcourt-against-dismissal

Thurén, L, 1990, The rhetorical strategy of 1 Pet. with special regard to ambiguous expressions, ÅBO Academy Press, Finland.

Tite, P.L., 1997, Compositional Transitions in 1 Peter: An analysis of the letter-opening, International Scholars Publications, San Francisco, CA.

Ukpong, J.S, 2006, 'African Interpretation', in The new interpreter's dictionary of the Bible, pp. 62-63, Abingdon, Nashville, TX. 